


\title{
Rule of law in the context of judicial reform as a direction of ensuring the accessibility of administrative proceedings
}

\author{
DOI: https://doi.org/10.46398/cuestpol.3969.44
}

\author{
Vyacheslav Tylchyk * \\ Olena Riabchenko ** \\ Khrystofor Yarmaki *** \\ Yurii Riabchenko **** \\ Viktor Leschynsky $* * * * *$
}

\begin{abstract}
The objective of the study is to analyze the rule of law in the context of the implementation of reforms of the judiciary, the judiciary, and related legal institutions as a direction to ensure the accessibility of administrative justice in Ukraine, revealing its relationship and interdependence. The study found that the availability of administrative procedures is provided by the requirements of all these generic subsystems of the principles that determine modern standards of activity in European countries. The methodology includes a comprehensive analysis and generalization of the available scientific and theoretical material, as well as the formulation of relevant conclusions. During the research, scientific cognition methods were used: terminological, logical-semantic, functional, system-structural, logical-normative, comparative. They highlight in the conclusions that the study found that the amendments to the Constitution of Ukraine in the context of judicial reform made it possible to revise the classical principles of the judiciary, but there are still important unresolved aspects to ensure full compliance with the rule of law, its specification in the constitutional provisions and legislative acts of Ukraine of substantive and procedural content, among
\end{abstract} other aspects.

* Professor, Head of the Department of Administrative Law and Process and Customs Security, Doctor of Law, University of State Fiscal Service of Ukraine, Ukraine. ORCID ID: https://orcid.org/oooo-ooo15964-3439. Email: tilchikvv@ukr.net

** Professor, Department of Administrative Law and Process and Customs Security, Doctor of Law, University of State Fiscal Service of Ukraine, Ukraine. ORCID ID: https://orcid.org/oooo-0001-66312830. Email: 80677171865@ukr.net

*** Professor, Department of Administrative law and procedure, Doctor of Law, Odessa State University of internal affairs: Odessa, Ukraine. ORCID ID: https://orcid.org/oooo-0oo1-7718-3093. Email: grek1951@ukr.net

****Associate Professor, Senior Lecturer, Department of Civil Law and Process, Doctor of Law University of the State Fiscal Service of Ukraine, Ukraine. Ukraine. ORCID ID: https://orcid.org/oooo-0002-1328700X. Email: 0971713748@ukr.net

***** Professor Iino Knuba, Chairman of the National Expert Building Alliance of Ukraine, Vice President of ABU, Candidate of Science in Public Administration. National Expert Building Alliance of Ukraine, Ukraine. ORCID ID: https://orcid.org/oooo-0oo1-6631-3456. Email: 80677171865@ukr.net 
Vyacheslav Tylchyk, Olena Riabchenko, Khrystofor Yarmaki, Yurii Riabchenko y Viktor Leschynsky

Keywords: rule of law; human rights; access to administrative justice; judicial reform; administrative procedures.

\section{El estado de derecho en el contexto de la reforma judicial como una dirección para garantizar la accesibilidad de los procedimientos administrativos}

\section{Resumen}

El objetivo del estudio es analizar el estado de derecho en el contexto de la implementación de reformas del poder judicial, el poder judicial y las instituciones legales relacionadas como una dirección para garantizar la accesibilidad de la justicia administrativa en Ucrania, revelando su relación e interdependencia. El estudio encontró que la disponibilidad de los procedimientos administrativos es proporcionada por los requisitos de todos estos subsistemas genéricos de los principios que determinan los estándares modernos de actividad en los países europeos. La metodología incluye un análisis integral y generalización del material científico y teórico disponible, así como la formulación de conclusiones relevantes. Durante la investigación se utilizaron los métodos de cognición científica: terminológico, lógico-semántico, funcional, sistema-estructural, lógiconormativo, comparativo. Destacan en las conclusiones que el estudio encontró que las enmiendas a la Constitución de Ucrania en el contexto de la reforma judicial permitieron revisar los principios clásicos del poder judicial, pero aún quedan aspectos importantes sin resolver para garantizar el pleno cumplimiento del estado de derecho, su especificación en las disposiciones constitucionales y actos legislativos de Ucrania de contenido sustantivo y procesal, entre otros aspectos.

Palabras clave: estado de derecho; derechoshumanos; acceso a lajusticia administrativa; reforma judicial; procedimientos administrativos.

\section{Introduction}

The urgency of the research is due to objective political, social, legal issues of judicial reform in Ukraine and ensuring access to justice, establishing adequate criteria for payment and gratuitous payment of court fees, court costs in general, which will improve the efficiency and effectiveness of good governance, implementation and protection of human and civil rights and freedoms in the sphere of executive power, formation of European standards of administrative justice. 
The term "rule of law" is used frequently in reference to a wide variety of desired end states. Neither scholars nor practitioners have settled upon an accepted definition. However, the term usually refers to a state in which citizens, corporations and the state itself obey the law, and the laws are derived from a democratic consensus. This is captured in a definition proposed by the United Nations (United Nations Security Council, 2004) The report containing this definition then suggests certain characteristics of the rule of law, including adherence to the principles of supremacy of law, equality before the law, fairness in application, separation of powers, participation in decision-making, legal certainty, avoidance of arbitrariness and procedural and legal transparency. The U.S. State Department's website similarly describes rule of law as protecting "fundamental political, social, and economic rights" and distinguishes between rule of law versus rule by law in more authoritarian societies.

\section{Literature review}

In the context of judicial reform, the content, and features of the introduction of the rule of law have been the subject of research by such scholars, politicians, judges, ideologues of judicial reform as Holovatyy (2019), Leheza et al., (2020), Pukhtetska (2010), Tylchyk Vyacheslav (2021), Tylchyk and Tylchyk (2021) and some others. A study and an analysis of evolutionary trends in interpretation are important from the point of view of increasing the efficiency and effectiveness of legal interpretation of the ECtHR and national authorities applying the ECHR, what is extremely important for parties recently acceded to the Convention. In legal systems of such member-states mainly technicaldogmatic methods of interpretation still prevail and judges don `t have the necessary skills to use international jurisprudence in the national legal system. The application of ECtHR's decisions in national practice allows solving not only problems of justice, but ones of a political, economic and social settlement (Karvatska et al., 2021).

Peculiarities of the ECtHR's interpretation are the special nature of international human rights treaties and of the ECHR in particular, what determines the actualisation of their interpretation in the context of the object and the purpose of treaties, in other words paying attention to the protection of individual rights, but not to the intentions of the member states in concluding the ECHR. There are also peculiarities of interpretation of institutional nature, which created certain differences at different stages of organizational transformation of the ECtHR (Karvatska et al., 2021). 
Vyacheslav Tylchyk, Olena Riabchenko, Khrystofor Yarmaki, Yurii Riabchenko y Viktor Leschynsky

An interpretational methodology developed by the ECtHR involves the use of its own methods, among which the methods of consensus, efficiency, judicial activism, comparison, innovative interpretation, autonomous method, and the method of "balancing" are becoming more and more exploited. The functioning of the ECtHR as a court, its interpretive method of building a holistic system through informal practice and setting standards by comparing the legal rules of member states, seem legitimate enough to define identifying evolutionary standards, and maximally contribute to their establishment and consolidation. The binding nature of ECtHR `s decisions only for parties to the dispute does not preclude, rather even affirms the need for the legislation of the Member States to comply with these standards, which must be sufficiently broad. Otherwise, the Court may be charged with "legislative" decisions. However, too broad standards make it incredibly difficult for the Court to operate (Karvatska et al., 2021).

A consensual examination allows the ECtHR to tie its decisions to the pace of changes in national law, recognising the political sovereignty of the respondent States and, at the same time, legitimising its own decisions against them, adhering to the principles of a democratic state governed by the rule of law (Karvatska et al., 2021).

\section{Results and discussion}

The current version of the Code of Administrative Procedure of Ukraine enshrines an approach developed based on anthropocentrism, developed in the context of constitutional and administrative reform, but its content needs to be improved to take into account modern requirements for the rule of law, in particular the accessibility of administrative proceedings. a set of financial, administrative, organizational, and technical guarantees, norms, regulations that provide not only formal but also real ability to provide judicial protection of violated rights in the system of administrative courts. For a long time, domestic legal thought was based on the principles of compliance with the rule of law, so the principle of legality occupied a central place in doctrinal and special legal research. Only a part of domestic scholars in the last ten years have begun to recognize the fundamental importance of the principle of the rule of law and its essential elements, the expediency of their introduction in the national doctrine and legal system.

The content and place of the rule of law are currently enshrined in the Constitution of Ukraine, special laws governing the activities of central government, in particular, the judiciary, but formal consolidation is not enough to implement the rule of law, it is necessary to develop an effective administrative mechanism and protection of human rights, which includes the development of criteria for the availability of administrative proceedings 
in Ukraine, taking into account the experience of leading European countries. It is necessary to trace national approaches to enshrining the requirements of the rule of law in national legislation on the judiciary, the status of judges, codified procedural acts in order to formulate proposals to update and detail the requirements of the rule of law in general and in particular - accessibility of administrative proceedings as a component of the rule of law in court administrative proceedings. According to the results of the analysis of the system of acts of legislation of Ukraine, the principle of the rule of law is mentioned in more than 300 acts of legislation.

The conducted quantitative analysis allows to testify that for the last twenty years there has been a significant implementation of the requirements of the rule of law in the current legislation of Ukraine, but the problems of interpretation of the content, the requirements of the rule of law, the grounds for appealing against non-compliance. various state institutions, primarily - the judiciary, because it is thanks to them is the counteraction to illegal actions, inaction of the subjects of power (Ivanenko, 2020). In this regard, the aspects of ensuring compliance with the requirements of accessibility of administrative proceedings, which should be a central component of domestic administrative procedural legislation, need a new solution. After all, by ensuring the availability of administrative justice, trust in the government and the state increases, and the rate of corruption and arbitrariness in society decreases. Comprehensive implementation of the requirements of the rule of law in its modern European sense will bring the domestic substantive and procedural legislation in line with the requirements of adaptation of Ukrainian legislation to the legislation of the European Union.

For the first time in Ukrainian legislation, the principle of the rule of law was enshrined at the level of the proposal of the National's Deputy Serhii Holovatyy to amend the article of the Constitution of Ukraine on the night before its adoption. Few people paid attention to this at that time, because mostly deputies were not acquainted with European and international acts, recommendations, and mostly relied on the high authority of the deputy, who dealt with this issue for more than twenty years. The definition of the rule of law enshrined in the Constitution of Ukraine has become epoch-making, as its definition has been disseminated in many other pieces of legislation, including by-laws. In all versions of the constitutions of independent Ukraine, the content of the rule of law has not changed, although aspects of its observance and the practice of judicial protection have developed significantly (Holovatyy, 2019).

Legislation on the status of judges, the judiciary, and the judiciary in Ukraine is one of the most reformed segments of national legislation, which reflects the key ideas of judicial and constitutional reform. Unfortunately, many other segments of domestic law are inferior in implementing the 
Vyacheslav Tylchyk, Olena Riabchenko, Khrystofor Yarmaki, Yurii Riabchenko y Viktor Leschynsky

ideas of the rule of law in various types of proceedings. The advantage of introducing the requirements of the rule of law in the legislation on the status of judges, the judiciary, the judiciary in Ukraine is: the presence of a clear formula, fixed in the procedural legislation; the existence of clearly defined grounds for the application of the case law of the European Court of Human Rights to review cases of violation of the principles of the rule of law by various actors; the existence of clearly defined principles of administrative proceedings, which directly fix the content and basic characteristics of the principle of the rule of law. In contrast, in several segments of the system of legislation of Ukraine still remain undefined content, meaning of the rule of law, as well as grounds for review of certain decisions, actions, inaction of authorized bodies due to non-compliance with the rule of law.

For example, this applies to legislation on civil service and reform of the responsibility of civil servants, legislation on the protection of citizens' rights, education, culture, social protection, which is dominated by previous positivist traditions of understanding the content of legal relations and their legal regulation. Turning to the analysis of legislative acts, we should first consider the provisions of the current Law of Ukraine: "On the Judiciary and the Status of Judges" of 02.06.2016 № 1402-VIII (On the Judiciary and the Status of Judges, 2016: 129), in which the principle of the rule of law is enshrined in the law as integral element, ambush, principle of justice. In particular, the direct fixation of the rule of law is enshrined in this law in Article 2, which states that: "The court, administering justice on the basis of the rule of law, guarantees everyone the right to a fair trial and respect for other rights and freedoms guaranteed by the Constitution and laws. Ukraine, as well as international treaties, the consent of which is given by the Verkhovna Rada of Ukraine" (On the Judiciary and the Status of Judges, 2016).

It is necessary to point out separately the provisions of Article 7 of the said law, in which in Part 3 of Art. 7 stipulates that: "Access to justice for every person is ensured in accordance with the Constitution of Ukraine and in the manner prescribed by the laws of Ukraine" (On the Judiciary and the Status of Judges, 2016: 130).

This is an important guarantee that contributes to the creation of statutory guarantees, the limits of possible behavior of subjects in the protection of violated rights in the courts. Unfortunately, the declared provisions are complex in their content and forms of implementation, so it is necessary to improve the administrative and legal provision of access to justice in general and sectoral manifestations.

Among the proposals aimed at developing the provisions of the analyzed law, it should be noted, first, the feasibility of creating legally defined, detailed requirements for compliance with the requirements of access to justice, dividing these aspects into the most important groups related to current 
issues of access to justice in general. in industrial aspects - pay attention to the expediency of special, high requirements to ensure accessibility, including administrative proceedings, as also in this area there are the most important human relationships and the state on behalf of government agencies and review their decisions in court. According to the results of the study, the content of the rule of law is still not sufficiently specified both among the key functional sections of the competence of central executive bodies and in bylaws, which leaves a large scope of research in both positive and controversial administrative proceedings.

In particular, in administrative proceedings, all illegal decisions made on the basis of and within the powers granted by law to executive authorities and local governments may be appealed. However, in the special laws governing their activities, the relevant requirements for compliance with the criteria of the rule of law are still not detailed, so in direct activities, interaction of executive bodies, local governments with citizens can often not clearly establish the legal basis for the rule of law. Therefore, the only effective way to protect violated requirements of the rule of law in positive administrative proceedings is to appeal to the administrative courts of Ukraine, and in most cases - outside the national jurisdiction, and appeal to the European Court of Human Rights due to lack of relevant legislation. provisions, state-building practices, etc (Leheza et al., 2018).

In our opinion, it is more expedient to analyze domestic legislation not only by normative assessment, verification of the formula for enshrining the rule of law in specific legislation, but also by their comprehensive analysis and relationship with the fundamental provisions of international and domestic legislation, which gradually implement the relevant requirements (Leheza et al., 2020).

The development of the rule of law is covered in several well-known documents of international and regional European organizations the United Nations, the European Union, the Council of Europe, the Organization for Security and Cooperation in Europe and many others, which reproduce the complex process of developing a global theoretical and legal approach. formation of unified fundamental principles of national legal systems (Leschynsky and Leschynsky, 2021).

In the European legal system, based on this principle, the principles of good governance and the principles of good administration have been developed. "The principles of good governance are one of the most important elements of the principle of the rule of law, are in direct connection with the fundamental principles of public administration. The difficulty of implementing the principles of good governance in Ukraine is due not only to the terminological and cognitive aspects, but also to a number of objectively existing factors that hinder this process: high levels of corruption, resistance to democratic reforms, including administrative and 
Vyacheslav Tylchyk, Olena Riabchenko, Khrystofor Yarmaki, Yurii Riabchenko y Viktor Leschynsky

legal direction within the apparatus of public administration, obsolescence of views and approaches to management both among civil servants and among scientists, researchers; biased attitude to the proposed models of reforms" (Tylchyk and Leschynsky, 2021).

The case law of the European Court of Human Rights is an important guideline for modern approaches to understanding the rule of law and its essential elements. Generalization of the practice of interpreting the content and elements of the principle of the rule of law was carried out in the scientific works of A. A. Pukhtetska, where it was determined that "as a result of systematization of decisions of the European Court of Human Rights, which contain provisions on the rule of law, to the main groups of decisions, which specify the content of the rule of law (given that in one case or decision may contain two or more features, essential elements of the principle of the rule of law in accordance with their understanding, formed by the case law of the European Court of Human Rights)" (Pukhtetska, 2010).

In particular, the cited study identified the following groups of cases of the European Court of Human Rights that are important for the implementation of the rule of law in Ukraine: "1) decisions of the European Court of Human Rights decisions containing references to the content, legal significance of the concept and / or the principle of the rule of law in the generalized sense; 2) the decision of the European Court of Human Rights, which contains requirements for the quality of law, including legal restrictions on the exercise of human rights and freedoms; 3) judgments of the European Court of Human Rights, which address various aspects of access to justice and a fair trial, which ensures a special mechanism of the Convention and compliance with the rule of law; 4) decisions of the European Court of Human Rights, which establish the limits of discretionary powers and requirements for limiting the arbitrariness of public authorities in accordance with the principle of the rule of law; 5) decisions of the European Court of Human Rights, which contain requirements for effective control over the exercise of human rights and fundamental freedoms guaranteed by the Convention, and are related to the implementation of the rule of law. This list of judgments of the European Court of Human Rights is not exhaustive but allows us to see the most typical aspects of the application of the rule of law and to help judges make a decision (Pukhtetska, 2009).

\section{Conclusion}

Amendments to the Constitution of Ukraine in the context of judicial reform have revised the classical principles of the judiciary of Ukraine, but still remain unresolved important aspects of ensuring full compliance with 
the rule of law, its specification in constitutional provisions and current legislation of Ukraine substantive and procedural content.

Interpretation of the concept, features, criteria of the rule of law in Ukrainian legislation is superficial, without proper specification of components and properties, the interdependence of these requirements with related concepts of good governance, proper administration, which are at the heart of modern European legislation and is a guideline for legal reforms.

In 2005, the content of the rule of law was enshrined in the context of key requirements in the Code of Administrative Procedure of Ukraine, however, the proposed approach to the interpretation of its content and essential features, in our opinion, remains quite limited, does not directly enshrine such essential elements as: accessibility judicial proceedings, proper legislation, quality of law, execution of court decisions, efficiency of decision-making, responsibility to private persons of public authorities.

It should be clarified that the availability of administrative proceedings is provided by the requirements of all these generic subsystems of the principles that determine modern standards of activity in European countries. In particular, they are combined with the requirements of appealing administrative decisions of all administrative bodies, as well as, in fact, the properties of administrative acts defined by law - require appeal all administrative acts that are contrary to the goals, objectives, competence of the administrative body, in violation of substantive or procedural law, as well as in case of fraud, etc.

Thus, the implementation of the requirements of accessibility of administrative proceedings is an integral part of the system of European standards of public administration.

\section{Bibliographic References}

HOLOVATYY, Serhii. 2019. Rule of law» does not work. Commentary on the text of a document of the Venice Commission. «Report on government». (Report on the Rule of Law), that it was adopted at the 86th plenary session. March 25-26, 2011 (CDL-AD (2011) 003re) Available online. In: https://www.venice.coe.int/files/articles/Holovaty_rule_of_law_ report_comments_2019.pdf. Date of consultation: 14/06/2020.

IVANENKO, Tetiana. 2020. "Availability of administrative proceedings as an element of the rule of law" in: Law and society. No. 6-2. Ch. 1, pp. 160164. 
Vyacheslav Tylchyk, Olena Riabchenko, Khrystofor Yarmaki, Yurii Riabchenko y Viktor Leschynsky

716

Rule of law in the context of judicial reform as a direction of ensuring the accessibility of administrative proceedings

KARVATSKA, Svitlana; BLIKHAR, Mariia; HURALENKO, Nataliia. 2021. "Evolutionary trends in the interpretation of the European Court of Human Rights under the European Convention on Human Rights" In: Cuestiones Políticas. Vol. 39, No. 68, pp. 88-102. Available online. In: https://doi.org/10.46398/cuestpol.3968.04. Date of consultation: 12/03/2021.

LEHEZA, Yevhen; FILIPENKO, Tatiana; SOKOLENKO, Olha; DARAHAN, Valerii; KUCHERENKO, Oleksii. 2020. "Ensuring human rights in ukraine: problematic issues and ways of their solution in the social and legal sphere" In: Cuestiones Políticas. Vol. 37, No. 64, pp 123-136. Available online. In: DOI: https://doi.org/10.46398/cuestpol.3764.10. Date of consultation: 12/12/2020.

LEHEZA, Yevhen; SAVIELIEVA, Maryna; DZHAFAROVA, Olena. 2018. "Structural and legal analysis of scientific activity regulation in developed countries" In: Baltic Journal of Economic Studies. Vol. 4, No. 3, pp. 147157.

PUKHTETSKA, Alla. 2010. "The principle of the rule of law: modern European doctrines as a guide for reforming national legislation" In: Bulletin of the National Academy of Sciences of Ukraine. Vol. 3. pp. 33-43.

PUKHTETSKA, Alla. 2009. "European principles of administrative law and their implementation in the legislation of Ukraine" For the degree of Cand. jurid. Science. Institute of State and Law. V.M. Koretsky NAS of Ukraine. Kyiv, Ukraine.

TYLCHYK, Vyacheslav; TYLCHYK, Olha. 2021. "Guarantees of legality of public administration activity: from concept to practical implementation" In: Baltic Journal of Economic Studies. Vol. 7, No. 1 (March), pp. 134-138. Available online. In: https://doi.org/10.30525/2256-0742/2021-7-1134-138. Date of consultation: 12/02/2021.

TYLCHYK, Vyacheslav; LESCHYNSKY, Viktor. 2021. "Public and Legal Relations as a Sphere of Judicial Protection of Violated Rights, Freedoms, and Interests" In: Baltic Journal of Economic Studies. Vol. 7, No. 2, pp. 17-21. Available online. In: https://doi.org/10.30525/22560742/2021-7-2-219-223. Date of consultation: 12/02/2021.

UNITED NATIONS SECURITY COUNCIL. 2004. "The Rule of Law and Transitional Justice in Conflict and Post Conflict Societies" In. Report of the Secretary General, August 23, pp. 4-6.

VERKHOVNA RADA OF UKRAINE. 2016. On the judiciary and the status of judges. Information of the Verkhovna Rada of Ukraine No. 31. Art. 545. Kyiv, Ukraine. 

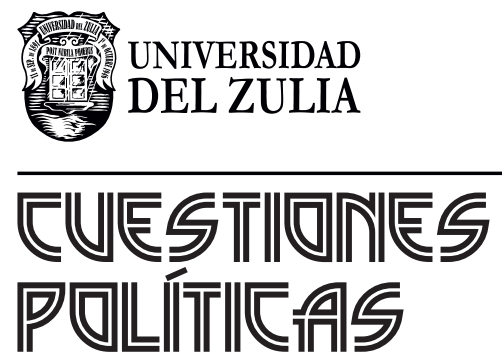

Vol.39 No 69

Esta revista fue editada en formato digital y publicada en julio de 2021, por el Fondo Editorial Serbiluz, Universidad del Zulia. Maracaibo-Venezuela 